\title{
THE MODE OF ACTION OF ANTRYCIDE
}

BY

\author{
W. E. ORMEROD
}

From the National Institute for Medical Research, Mill Hill, London, N.W.7

(Received March 21, 1951)

This paper deals with the mode of action of "Antrycide"* on trypanosomes in vitro and in the living animal. Although the particular virtue of antrycide is its activity against $T$. congolense, in the experiments reported here a strain of $T$. equiperdum which has been maintained in this laboratory for routine drug standardization was used. This strain has the advantages that it produces a constant acute infection with high blood parasite counts in rats and mice, that it is fatal for untreated animals within a period that can be predicted according to the degree of infection, and that it survives in vitro. Although Curd and Davey (1950) showed that there are large quantitative differences in the susceptibility of species of trypanosomes to antrycide there is no reason to suppose that any qualitative differences exist except between the susceptible strains and $T$. cruzi which they found insusceptible to antrycide. In this paper, when the species of trypanosome is not mentioned $T$. equiperdum was used. Where it was necessary to make sure that any particular finding was not an individual strain characteristic, strains of $T$. rhodesiense and $T$. congolense were used.

I should like to thank Messrs. Imperial Chemical (Pharmaceuticals), Ltd., for a gift of antrycide methylsulphate; this salt has been used throughout, except where otherwise stated.

How the resistant strain of $T$. equiperdum used in these experiments was formed will be described in a later publication.

\section{EXPERIMENTS}

The effect of antrycide on trypanosomes in vitro

Trypanosomes were incubated at $37^{\circ} \mathrm{C}$. with varying concentrations of the drug. The method used, based on that of Yorke, Adams, and Murgatroyd (1929), was as follows :

A rat showing trypanosomes in the blood in the order of 20 per high-power microscopic field was killed by immersion in pure $\mathrm{CO}_{2}$. Blood taken from the heart was suspended in sterile 1.5 per cent citrate saline, to prevent clotting, and a washing fluid consisting of 1 volume horse serum to 9 volumes Ringer's solution. This mixture was centrifuged lightly in order to remove blood cells and leave the trypanosomes in the supernatant fluid, which was then put into fresh vessels. The trypanosomes were centrifuged down and resuspended in the final diluting fluid, which consisted of 4 volumes Ringer's solution to 1 volume pooled serum from normal rats. A drop of this fluid containing

\footnotetext{
* Trade mark of Imperial Chemical (Pharmaceuticals) Ltd.
} 
trypanosomes was then added to each of a series of tubes containing varying concentrations of antrycide in $\mathbf{0 . 2}$ per cent glucose Ringer's solution. The trypanosomes were counted at intervals, and their infectivity estimated by injecting the whole contents of a tube into a mouse.

A typical experiment is shown in Table I. Very little trypanocidal action can be seen in experiments such as that recorded in Table I, where the trypanosomes were taken from a rat with rising infection. There was, however, a more marked but somewhat irregular loss of infectivity which could also be demonstrated when the

TABLE I

ACTION OF ANTRYCIDE ON TRYPANOSOMES in vitro

Table showing a typical experiment with a normal strain of $T$. equiperdum incubated with antrycide. The figures in the column headed "Trypanosomes $\times 1,000$ per cu.mm." represent the concentration in each tube, which contained 0.25 c.c. of fluid; this was injected into a mouse at the time of counting

++ Mouse infected within three days. + Mouse infected within 10 days. - Mouse uninfected

\begin{tabular}{|c|c|c|c|c|c|c|c|c|c|}
\hline \multirow{3}{*}{$\begin{array}{l}\text { Concentration } \\
\text { of antrycide }\end{array}$} & & \multicolumn{8}{|c|}{ Results after incubation for } \\
\hline & & \multicolumn{2}{|c|}{$5 \mathrm{~min}}$. & \multicolumn{2}{|c|}{$2 \frac{1}{2} \mathrm{hr}$} & \multicolumn{2}{|c|}{$4 \frac{1}{2} \mathrm{hr}$. } & \multicolumn{2}{|c|}{$20 \mathrm{hr}$. } \\
\hline & 11 & $\begin{array}{c}\text { Trypano- } \\
\text { somes } \\
\times 1,000 \\
\text { per cu.mm. }\end{array}$ & $\begin{array}{l}\text { Infec- } \\
\text { tivity }\end{array}$ & $\begin{array}{c}\text { Trypano- } \\
\text { somes } \\
\times 1,000 \\
\text { per cu.mm. }\end{array}$ & $\begin{array}{l}\text { Infec- } \\
\text { tivity }\end{array}$ & $\begin{array}{c}\text { Trypano- } \\
\text { somes } \\
\times 1,000 \\
\text { per cu.mm. }\end{array}$ & $\begin{array}{l}\text { Infec- } \\
\text { tivity }\end{array}$ & $\begin{array}{c}\text { Trypano- } \\
\text { somes } \\
\times 1,000 \\
\text { per cu.mm. }\end{array}$ & $\begin{array}{l}\text { Infec- } \\
\text { tivity }\end{array}$ \\
\hline $\begin{array}{l}1 / 20,000 \\
1 / 40,000 \\
1 / 80,000 \\
1 / 160,000 \\
1 / 320,000 \\
1 / 640,000 \\
\text { Control } \\
\text { Control }\end{array}$ & $\begin{array}{l}\cdots \\
\cdots \\
\cdots \\
\cdots \\
\cdots \\
\cdots\end{array}$ & $\begin{array}{l}36 \\
36 \\
36 \\
36 \\
36 \\
36 \\
36 \\
36\end{array}$ & $\begin{array}{c}++ \\
- \\
++ \\
++ \\
++ \\
++ \\
++ \\
++\end{array}$ & $\begin{array}{l}22.0 \\
24.8 \\
34.8 \\
10.8 \\
36.0 \\
35.6 \\
36.4 \\
30.8\end{array}$ & $\begin{array}{l}- \\
- \\
+ \\
+ \\
+ \\
- \\
++ \\
++\end{array}$ & $\begin{array}{l}19.2 \\
22.0 \\
26.4 \\
35.2 \\
26.0 \\
23.6 \\
30.4 \\
31.6\end{array}$ & $\begin{array}{l}- \\
- \\
+ \\
- \\
+ \\
+ \\
++ \\
++\end{array}$ & $\begin{array}{l}0 \\
3.6 \\
2.0 \\
9.2 \\
9.2 \\
2.8 \\
4.4 \\
4.0\end{array}$ & $\begin{array}{l}- \\
- \\
- \\
- \\
- \\
\overline{+} \\
+\end{array}$ \\
\hline
\end{tabular}

trypanosomes were washed free from antrycide-containing fluid. In other experiments where the infection was further advanced, high concentrations of the order of $1 / 80,000$ killed a proportion of the trypanosomes; this effect varied widely from one experiment to another both in the number of trypanosomes killed and in the time taken for the effect to appear. Trypanocidal activity was never observed at concentrations as low as those achieved in vivo, i.e., of the order of $1 / 1,000,000$ (Spinks, 1950).

Because of the variability of results with normal strains of trypanosomes it is not possible to give any strict comparison of results with resistant strains. There was, however, no detectable difference between normal and resistant strains either in their susceptibility to trypanocidal action or in their loss of infectivity.

The serum of a rat 24 hours after an effective dose of antrycide showed no activity against trypanosomes in vitro.

The effect of antrycide on the respiration of trypanosomes in vitro was measured by the Warburg technique. Whole blood from the heart of a rat killed by $\mathrm{CO}_{2}$ was treated with sufficient citrate saline to prevent clotting; this was added to the main compartment of the Warburg flask, which already contained the required dilution of 
antrycide in Ringer's solution with 0.2 per cent glucose. The final number of trypanosomes was 1-2 thousand million per 3 c.c. fluid in the main compartment of each flask ; the centre compartment of each flask contained 0.2 c.c. 20 per cent $(w / v) \mathrm{KOH}$.

No inhibition was observed with concentrations of antrycide less than $1 / 80,000$, and the normal decline in oxygen consumption when the glucose in the medium was used up occurred at the same time as in controls. Some inhibition was, however, observed at $1 / 40,000$ and varied in different experiments from 20-50 per cent of controls at one hour from the beginning of the experiment. Inhibition was also observed at the same concentration with a resistant strain.

It is unlikely that either the inhibition of respiration or the trypanocidal effect in vitro is in any way connected with the therapeutic effect of antrycide ; it is more likely to be an incidental physical effect such as the precipitation of antrycide chloride on the cell membrane. The limit of solubility of antrycide chloride in Ringer's solution at $37^{\circ} \mathrm{C}$. is approximately $1 / 25,000$, and it is readily precipitated from saline solutions made from the methylsulphate.

Action of antrycide in vivo

Infected mice were dosed intraperitoneally with antrycide in distilled water; the trypanosomes in the blood continued, however, to increase after dosing, although after an effective dose the rate of increase was less than in controls. A large dose given in an early infection could prevent the rise in trypanosome count, although this was often difficult to achieve in mice owing to the toxicity of the drug. After a normal curative dose a peak of infection was reached after 24-48 hours and the blood cleared of trypanosomes in 2-4 days. Table II shows the response of an

TABLE II

RESPONSE OF AN INFECTION WITH $T$. equiperdum TO ANTRYCIDE

The antrycide was given intraperitoneally on the first day of infection (LD50 intraperitoneal antrycide for Parkes strain mice $\simeq 0.34 \mathrm{mg} . / 20 \mathrm{~g}$.)

$\mathrm{R}=$ Relapsed on the 9 th day. $\mathrm{N}=$ Negative for 15 days. + Died

\begin{tabular}{|c|c|c|c|c|c|c|c|c|}
\hline \multirow{2}{*}{$\begin{array}{l}\text { Days of } \\
\text { Infection }\end{array}$} & \multicolumn{8}{|c|}{$\begin{array}{l}\text { Extent of infection after varying doses of antrycide in terms of trypanosomes } \\
\text { per field or per } 20 \text { fields }\end{array}$} \\
\hline & \multicolumn{2}{|c|}{$0.05 \mathrm{mg} . / 20 \mathrm{~g}$. } & \multicolumn{2}{|c|}{$0.1 \mathrm{mg} . / 20 \mathrm{~g}$} & \multicolumn{2}{|c|}{$0.2 \mathrm{mg} . / 20 \mathrm{~g}$} & \multicolumn{2}{|c|}{ Controls } \\
\hline $\begin{array}{r}1 \\
2 \\
3 \\
5 \\
>5\end{array}$ & $\begin{array}{c}7 / 1 \\
16 / 1 \\
10 / 1 \\
0 / 20 \\
\mathrm{R}\end{array}$ & $\begin{array}{c}3 / 1 \\
7 / 1 \\
8 / 1 \\
0 / 20 \\
\mathrm{~N}\end{array}$ & $\begin{array}{l}2 / 20 \\
2 / 1 \\
2 / 1 \\
0 / 20 \\
\mathrm{~N}\end{array}$ & $\begin{array}{l}2 / 1 \\
7 / 1 \\
5 / 1 \\
0 / 20 \\
\mathrm{~N}\end{array}$ & $\begin{array}{c}16 / 20 \\
1 / 1 \\
3 / 20 \\
0 / 20 \\
\mathrm{~N}\end{array}$ & $\begin{array}{l}9 / 1 \\
8 / 1 \\
5 / 1 \\
0 / 20 \\
\mathrm{~N}\end{array}$ & $\begin{array}{r}6 / 1 \\
20+/ 1 \\
+\end{array}$ & $\begin{array}{c}6 / 20 \\
14 / 1 \\
+\end{array}$ \\
\hline
\end{tabular}

infection of $0.05 \mathrm{mg} . / 20 \mathrm{~g}$., a dose af:er which some relapses occur ; to $0.1 \mathrm{mg} . / 20 \mathrm{~g}$., a normal curative dose ; and to $0.2 \mathrm{mg} . / 20 \mathrm{~g}$., the maximum dose that can be given without mortality.

Trypanosomes may remain in the blood for several days after a dose of antrycide, but their infectivity is markedly reduced, as is shown in Table III. In Exp. A an ineffective dose was given to the donor, and the result was only a slight loss of infectivity; in (B) after an effective dose the infectivity of the trypanosomes was diminished $3 / 4$ and 4 hours after dosing, and was abolished after 24 hours, so that none of the mice injected at that time became infected in 17 days. 
TABLE III

EFFECT OF ANTRYCIDE ON INFECIIVITY

Table showing the proportion of mice that became infected after passage from donor animals dosed with antrycide. Donor animals were infected (20 trypanosomes per field) and passage was effected at various intervals after dosage with antrycide. (A) represents an ineffective and (B) an effective dose. Within each group a standard number of trypanosomes was injected into each mouse

\begin{tabular}{|c|c|c|c|c|c|c|c|}
\hline \multirow{2}{*}{$\begin{array}{l}\text { Donor } \\
\text { species } \\
\text { and dose }\end{array}$} & \multirow{2}{*}{$\begin{array}{l}\text { Days } \\
\text { after } \\
\text { passage }\end{array}$} & \multirow{2}{*}{ Controls } & \multicolumn{5}{|c|}{ Mice infected/mice injected at intervals after antrycide } \\
\hline & & & $\frac{1}{2} \mathrm{hr}$. & $\frac{3}{4} \mathrm{hr}$. & $3 \mathrm{hr}$. & $4 \mathrm{hr}$. & $24 \mathrm{hr}$. \\
\hline $\begin{array}{c}\text { A } \\
\text { Mouse } \\
0.04 \mathrm{mg} / 20 \mathrm{~g} .\end{array}$ & $\begin{array}{l}1 \\
2 \\
4 \\
5\end{array}$ & $3 / 3$ & $9 / 9$ & & $\begin{array}{l}7 / 8 \\
8 / 8\end{array}$ & & $\begin{array}{c}0 / 10 \\
0 / 10 \\
5 / 10 \\
9 / 9 \text { (one } \\
\text { mouse died) }\end{array}$ \\
\hline$\underset{0.1}{\stackrel{B}{\text { Rat }} \text { mg. } / 20 \mathrm{gg} .}$ & $\begin{array}{r}2 \\
4 \\
10 \\
17\end{array}$ & $10 / 10$ & & $\begin{array}{l}0 / 10 \\
0 / 10 \\
3 / 10 \\
4 / 10\end{array}$ & & $\begin{array}{l}0 / 10 \\
0 / 10 \\
1 / 10 \\
6 / 10\end{array}$ & $\begin{array}{l}0 / 10 \\
0 / 10 \\
0 / 10 \\
0 / 10\end{array}$ \\
\hline
\end{tabular}

Morphological changes in trypanosomes treated with antrycide

Although trypanosomes treated with antrycide appear normal when examined in wet films, their loss of infectivity indicates that they must have undergone some change. Serial counts were therefore made, using stained dry smears, in order to detect any possible change in the rate of cell division. The trypanosomes were counted as: (1) Normal resting forms. (2) Dividing forms; for the purposes of the count, "dividing forms" included all trypanosomes showing divided blepharoplasts, or two flagellae, or a nucleus showing a pale band across the middle caused probably by the migration of chromatin to its opposite poles. (3) Binuclear forms showing two nuclei.

Table IV shows one such series of counts. The variability from animal to animal and from experiment to experiment is considerable, particularly in regard to the number of binuclear forms in trypanosomes from treated animals. However, the three following features, besides the gradual death of the trypanosomes, were unmistakable in this and two similar experiments:

1. The appearance of mis-shapen cells damaged presumably in making the slide.

2. A general decrease in the number of dividing forms; this was not apparent until late in the experiment when the trypanosome counts were beginning to fall.

3. The appearance of deep violet staining inclusion bodies in the cytoplasm in groups or large masses, often cramming the cell and obliterating other features of the internal structure. These were the first abnormalities to appear in treated trypanosomes, and were present after 24 hours in every animal that had received a therapeutic dose. They persisted as long as trypanosomes remained in the blood, but occasionally at the end of the third or on the fourth day the highly degenerate trypanosomes remaining in the blood did not contain inclusion bodies but showed 
TABLE IV

Table showing: 1. Degree of infection in trypanosomes per field or per 20 fields. 2. The percentage-resting, dividing, binuclear, and mis-shapen forms in three mice treated with $0.05 \mathrm{mg} .20 \mathrm{~g}$. antrycide and three control mice. 3. The appearance of inclusion bodies noted with a star. $0.05 \mathrm{mg}$. antrycide per $20 \mathrm{~g}$. produced inclusion bodies in all the trypanosomes and cleared all trypanosomes from the blood in $120 \mathrm{hr}$.

\begin{tabular}{|c|c|c|c|c|c|c|c|c|c|c|}
\hline & \multirow{4}{*}{ Forms } & \multirow[t]{4}{*}{. } & \multicolumn{8}{|c|}{ At 47 hours $0.05 \mathrm{mg} . / 20 \mathrm{~g}$. antrycide was given } \\
\hline & & & \multicolumn{8}{|c|}{ Hours after infection } \\
\hline & & & \multicolumn{2}{|l|}{44} & \multicolumn{2}{|l|}{68} & \multicolumn{2}{|l|}{72} & \multicolumn{2}{|l|}{92} \\
\hline & & & $\begin{array}{l}\text { Degree of } \\
\text { infection }\end{array}$ & $\begin{array}{c}\% \\
\text { Forms }\end{array}$ & $\begin{array}{l}\text { Degree of } \\
\text { infection }\end{array}$ & $\begin{array}{c}\% \\
\text { Forms }\end{array}$ & $\begin{array}{l}\text { Degree of } \\
\text { infection }\end{array}$ & $\begin{array}{c}\% \\
\text { Forms }\end{array}$ & $\begin{array}{l}\text { Degree cf } \\
\text { infection }\end{array}$ & $\begin{array}{c}\% \\
\text { Forms }\end{array}$ \\
\hline \multirow{3}{*}{ 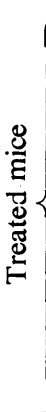 } & $\left\{\begin{array}{l}\text { Resting .. } \\
\text { Dividing } \\
\text { Binuclear } \\
\text { Mis-shapen }\end{array}\right.$ & $\begin{array}{l}\cdots \\
\cdots \\
\cdots\end{array}$ & $2 / 1$ & $\begin{array}{r}80 \\
15 \\
5 \\
0\end{array}$ & $\begin{array}{l}5 / 1 \\
*\end{array}$ & $\begin{array}{r}71 \\
20 \\
9 \\
0\end{array}$ & $\begin{array}{c}4 / 1 \\
*\end{array}$ & $\begin{array}{r}79 \\
9 \\
7 \\
12\end{array}$ & $\begin{array}{l}1 / 1 \\
*\end{array}$ & $\begin{array}{r}62 \\
0 \\
12 \\
24\end{array}$ \\
\hline & $\begin{array}{l}\text { Resting .. } \\
\text { Dividing } \\
\text { Binuclear } \\
\text { Mis-shapen }\end{array}$ & $\begin{array}{l}\ldots \\
\cdots \\
\cdots\end{array}$ & $7 / 29$ & $\begin{array}{r}90 \\
15 \\
5 \\
0\end{array}$ & $\begin{array}{c}3 / 1 \\
*\end{array}$ & $\begin{array}{r}80 \\
1 \\
7 \\
6\end{array}$ & $\begin{array}{c}4 / 1 \\
*\end{array}$ & $\begin{array}{r}71 \\
1 \\
4 \\
24\end{array}$ & $\begin{array}{c}15 / 20 \\
*\end{array}$ & $\begin{array}{r}66 \\
2 \\
0 \\
32\end{array}$ \\
\hline & $\begin{array}{l}\text { Resting ... } \\
\text { Dividing } \\
\text { Binuclear } \\
\text { Mis-shapen }\end{array}$ & $\begin{array}{l}\cdots \\
\cdots \\
\cdots\end{array}$ & $1 / 1$ & $\begin{array}{r}82 \\
11 \\
7 \\
0\end{array}$ & $\begin{array}{c}15 / 20 \\
*\end{array}$ & $\begin{array}{r}75 \\
13 \\
9 \\
3\end{array}$ & $\begin{array}{c}3 / 1 \\
*\end{array}$ & $\begin{array}{r}80 \\
4 \\
1 \\
15\end{array}$ & $\begin{array}{c}2 / 1 \\
*\end{array}$ & $\begin{array}{r}78 \\
4 \\
11 \\
7\end{array}$ \\
\hline \multirow{3}{*}{ 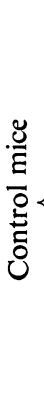 } & $\begin{array}{l}\text { Resting } \\
\text { Dividing } \\
\text { Binuclear } \\
\text { Mis-shapen }\end{array}$ & $\begin{array}{l}\cdots \\
\cdots \\
\cdots\end{array}$ & $9 / 20$ & $\begin{array}{r}80 \\
13 \\
7 \\
0\end{array}$ & $20+/ 1$ & $\begin{array}{r}89 \\
10 \\
1 \\
0\end{array}$ & $20+/ 1$ & $\begin{array}{r}91 \\
8 \\
1 \\
0\end{array}$ & $20+/ 1$ & $\begin{array}{r}67 \\
22 \\
11 \\
0\end{array}$ \\
\hline & $\begin{array}{l}\text { Resting } \\
\text { Dividing } \\
\text { Binuclear } \\
\text { Mis-shapen }\end{array}$ & $\begin{array}{l}\cdots \\
\cdots \\
\cdots\end{array}$ & $3 / 1$ & $\begin{array}{r}85 \\
15 \\
0 \\
0\end{array}$ & $14 / 1$ & $\begin{array}{r}82 \\
16 \\
2 \\
0\end{array}$ & $20+/ 1$ & $\begin{array}{r}75 \\
17 \\
7 \\
0\end{array}$ & $20+/ 1$ & $\begin{array}{r}63 \\
32 \\
5 \\
0\end{array}$ \\
\hline & $\begin{array}{l}\text { Resting ... } \\
\text { Dividing } \\
\text { Binuclear } \\
\text { Mis-shapen }\end{array}$ & $\begin{array}{l}\cdots \\
\cdots \\
\cdots\end{array}$ & $12 / 20$ & $\begin{array}{r}68 \\
29 \\
3 \\
0\end{array}$ & $15 / 1$ & $\begin{array}{r}85 \\
9 \\
6 \\
0\end{array}$ & $20+/ 1$ & $\begin{array}{r}75 \\
17 \\
8 \\
0\end{array}$ & $20+/ 1$ & $\begin{array}{r}66 \\
32 \\
2 \\
0\end{array}$ \\
\hline
\end{tabular}

very pale cytoplasm, as though, in losing the inclusion bodies, staining material had gone out of the cell. In occasional mice, maximal doses of antrycide failed to produce inclusion bodies and the cells degenerated without undergoing any specific change. An ordinary curative dose always produced inclusion bodies in the normal strains of $T$. equiperdum, $T$. congolense, and $T$. rhodesiense used. After such a dose all trypanosomes were to some degree affected, but their appearance differed widely in animals of the same species treated similarly; they were produced equally well in rats and mice. After an ineffective dose only a fraction of the trypanosomes contained inclusion bodies ; this appearance was also produced in a partially resistant strain. With a totally resistant strain no inclusion bodies were produced. 
These inclusion bodies, shown in Plates 1 and 2, stained a deep violet with the usual eosin-methylene blue compound stains, freshly prepared Leishman giving the best results; the cytoplasm retained its usual basophilia but in some instances appeared paler than usual. They were not usually visible in unstained trypanosomes except with phase contrast microscopy, when in the living and actively motile trypanosome they appeared as highly refractile granules contrasting with the paler

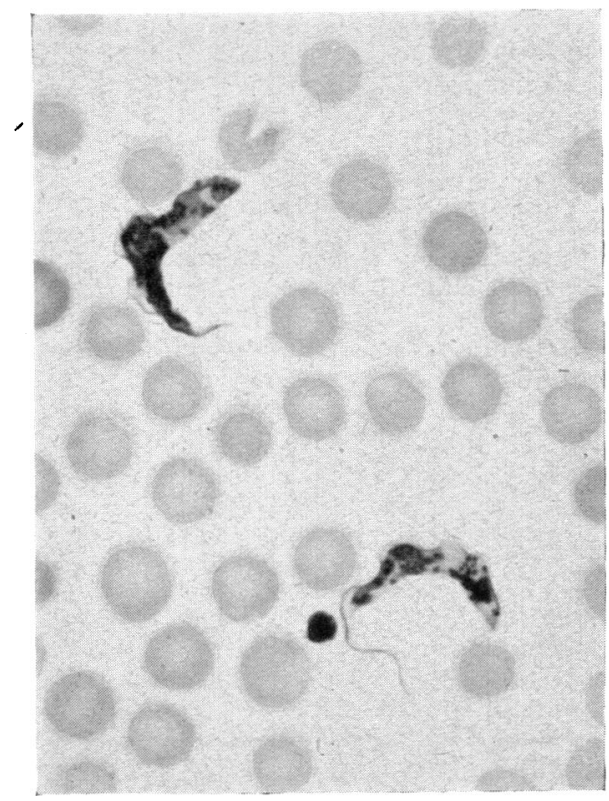

Plate 1.-T. equiperdum in rat. Inclusion bodies produced by antrycide, $10 \mathrm{mg} . / \mathrm{kg}$. Stained with Leishman.

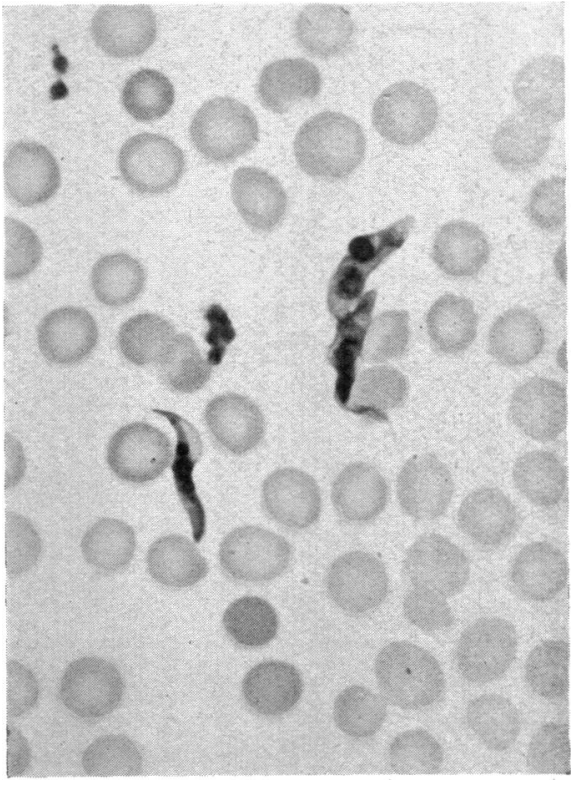

Plate 2.- $T$. congolense in mouse. Inclusion bodies produced by antrycide, $1.0 \mathrm{mg} . / \mathrm{kg}$. Stained with Leishman.

cytoplasm and nucleus. They did not seem in any way to impede the trypanosomes, which were normal except for these inclusion bodies and a slight distension of the pale basal vacuole. A similar appearance can be seen in the dried unfixed preparation under the fluorescence microscope, when trypanosomes from an animal treated with antrycide show faintly fluorescent bodies (see Plate 3). The largest in some trypanosomes corresponds to the basal vacuole, but the others have a similar distribution to the inclusion bodies as shown by other methods, and it is most probable that the remainder of the absorbed antrycide is concentrated in these inclusion bodies. No fluorescence could be detected in the nucleus of the trypanosome.

\section{Multinuclear forms}

In the experiment shown in Table IV and in other similar experiments with $T$. equiperdum, cells with more than two nuclei were only seen on three occasions. $T$. rhodesiense appears, however, to produce multinuclear forms more readily. In the strain used, $0.05 \mathrm{mg}$. antrycide per $20 \mathrm{~g}$. was necessary to clear the blood of 


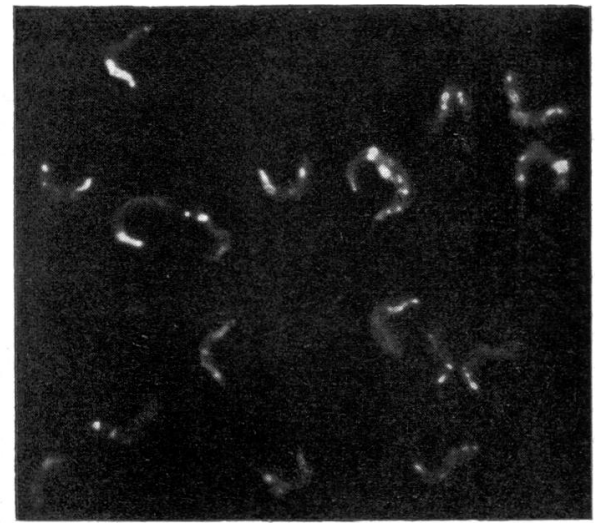

Plate 3.-T. equiperdum in mouse. Fluorescent inclusion bodies produced by antrycide, 2.5 mg./kg. Fluorescence photomicrograph taken with an Osira lamp, Woods glass filter transmission maximum 3650A, and sensitive emulsion exposed for one hour. The fluorescent drug can be seen concentrated in the inclusion bodies.

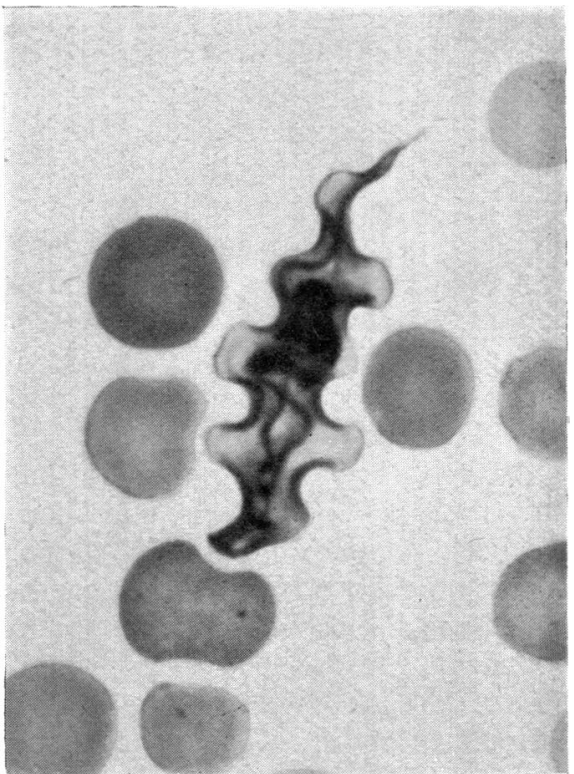

Plate 4.-T. rhodesiense in mouse. Stained with Leishman. Multinuclear forms produced by antrycide, $0.5 \mathrm{mg}$./kilo. A few of these abnormal cells are produced in the blood of a mouse treated with $1 / 5$ th dose necessary to clear the blood. Division of the cell wall is inhibited, but internal structures continue to divide.

trypanosomes, but in mice that had been given one-fifth of this dose, up to 5 per cent of the trypanosomes had more than two nuclei. The trypanosome in Plate 4 is an extreme example with six nuclei, three blepharoplasts, and four flagellae, showing that division of the cytoplasm and cell membrane has bean inhibited by the drug, but the internal structures have continued to divide.

\section{Discussion}

As the molecule of antrycide is large and contains two permanent positive charges, it seemed likely that its action was on the surface of the trypanosome in the manner of a cationic detergent. On the surface membrane antrycide might act either by inhibiting surface enzymes, or indirectly by covering the trypanosome and "starving it out." The first of these possibilities is easily eliminated by the delay before any activity can be observed in animals given a dose of antrycide ; an indirect action on the surface is less easily eliminated, but it is most likely that trypanosomes affected in this way would be moribund, whereas when inclusion bodies are fully developed in trypanosomes, and their infectivity abolished by a dose of antrycide, they are still actively motile and cannot be distinguished from normal trypanosomes in the ordinary wet film. Finally, trypanosomes that have been treated with antrycide show a faint fluorescence which comes chiefly from structures similar to those that appear in the cytoplasm in stained preparations. 
All this strongly suggests that antrycide penetrates slowly into the cell and exerts its action there and not upon the surface membrane.

There is no indication that the primary action of antrycide is upon the nucleus. The evidence suggests either that nuclear changes occur as a result of cytoplasmic changes or that antrycide penetrates the nuclear membrane after affecting the cytoplasm: (a) Inhibition of nuclear division occurs late in the cycle of events. (b) Cell division can be inhibited independently of nuclear division. (c) Fluorescence of antrycide has not been observed in the part of the cell occupied by the nucleus. There is, however, strong evidence that the drug acts upon the cytoplasm where abnormal inclusion bodies can be seen in the living trypanosome under phase contrast at a time when similar, if not identical structures, show the fluorescence of antrycide in the dry unfixed film.

There is no evidence to suggest that antrycide inhibits enzymes or the utilization of metabolites (Town, Wills, and Wormall, 1949), although no experiments in vitro have been successfully carried out on trypanosomes in the late stages of contact with the drug when it will have been absorbed. But whether or not it acts by inhibiting cell metabolism it is clear that it is a growth inhibitor rather than a direct trypanocide ; this is shown by: (a) Absence of trypanocidal effect in vitro. (b) In $T$. rhodesiense a small dose of antrycide can inhibit cell division while nuclear division continues. (c) Trypanosomes can remain circulating in the blood and actively motile after a dose of antrycide that has produced structural changes and rendered them non-infective; all vital functions appear intact except the ability to reproduce.

\section{SUMMARY}

1. Antrycide has been shown to be without trypanocidal action in vitro at higher concentrations than can be achieved in vivo during observation periods up to 20 hours.

2. Similar high concentrations have no observable effect in vitro on the respiration and glucose utilization in trypanosomes.

3. Still higher concentrations of the order of $1 / 20,000$ which do show some trypanocidal activity in vitro and inhibit the respiration of trypanosomes are equally active against normal and antrycide-resistant trypanosomes.

4. An effective dose of antrycide may take from two to four days to clear trypanosomes from the blood of a mouse, but after 24 hours the circulating trypanosomes will not infect fresh mice.

5. After an effective dose, basophilic inclusion bodies appear in the cytoplasm of all trypanosomes in the blood 24 hours after dosing. These bodies can also be seen in the living trypanosome by phase contrast microscopy.

6. Twenty-four hours after a dose of antrycide, faintly fluorescent bodies can be seen in the cytoplasm of trypanosomes. It is suggested that some of the largest of these correspond to the distended basal vacuole and the others to the inclusion bodies mentioned above.

7. From 24 hours after an effective dose the number of trypanosomes showing signs of division diminishes slowly. 
8. T. rhodesiense reacts to a small dose of antrycide by producing multinuclear forms.

9. Three conclusions are put forward and discussed:

(a) Antrycide penetrates slowly into the cell and exerts its action in the cell and not on the surface membrane.

(b) The action of antrycide is on the cytoplasm and not primarily on the nucleus.

(c) Antrycide in normal curative doses acts as a growth inhibitor and not as a direct " trypanocide."

I should like to express my thanks to Dr. F. Hawking, who proposed that I should investigate the mode of action of antrycide, for his interest and stimulating criticism; to Mr. J. Smiles and his staff for their interest and co-operation, to which I owe the illustrations and much of the substance of this work ; and to my assistants Mr. D. Cragoe, Mr. F. Jabir, and Mr. C. Hill.

\section{REFERENCES}

Curd, F. H. S., and Davey, D. G. (1950). Brit. J. Pharmacol., 5, 25.

Spinks, A. (1950). Brit. J. Pharmacol., 5, 445.

Town, B. W., Wills, E. D., and Wormall, A. (1949). Nature, Lond., 164, 233.

Yorke, W., Adams, A. R. D., and Murgatroyd, F. (1929). Ann. trop. Med. Parasit., 23, 501. 